\title{
Reticulo-rumen mass, epithelium gene expression, and systemic biomarkers of metabolism and inflammation in Holstein dairy cows fed a high-energy diet
}

\author{
J. M. Arroyo, ${ }^{\dagger} †$ A. Hosseini, ${ }^{*}$ Z. Zhou, ${ }^{\ddagger} \ddagger$ A. Alharthi, ${ }^{*}$ E. Trevisi,§ J. S. Osorio,\# ${ }^{1}$ and J. J. Loor ${ }^{* 1}$ \\ *Department of Animal Sciences and Division of Nutritional Sciences, University of Illinois, Urbana 61801 \\ †Departamento de Nutrición Animal, Instituto de Producción Animal, Facultad de Veterinaria, Universidad de la Republica, Ruta 1 km 42.5 , \\ 80100, San José, Uruguay \\ $\ddagger$ Animal and Veterinary Sciences, Clemson University, 146 Poole Agricultural Center, Clemson University, Clemson, SC 29634 \\ §Istituto di Zootecnica, Facoltà di Scienze Agrarie, Alimentari e Ambientali, Università Cattolica del Sacro Cuore, 29122, Piacenza, Italy \\ \#Department of Dairy Science, South Dakota State University, Brookings 57007
}

\begin{abstract}
Feeding a higher-energy diet by increasing cereal grains at the expense of forage during the last 3 to 4 wk prepartum is a traditional approach to help the rumen "adapt" to the traditional diets fed at the onset of lactation. Increasing grain/concentrate in the diet changes ruminal fermentation and in sheep and goats elicits marked changes in mRNA expression of immunerelated genes in ruminal epithelium. Whether such changes at the epithelial and systemic levels occur in dairy cows when the dietary energy content increases at a fixed level of concentrate is unknown. Fourteen nonpregnant, nonlactating Holstein cows were fed a control lower-energy (CON, $1.30 \mathrm{Mcal} / \mathrm{kg}$ of dry matter) diet to meet $100 \%$ of estimated nutrient requirements for $3 \mathrm{wk}$, after which half of the cows were assigned to a higher-energy diet (OVE, $1.60 \mathrm{Mcal} / \mathrm{kg}$ of dry matter) and half of the cows continued on CON for 6 wk. Levels of forage and concentrate for CON and OVE were 80 and $79 \%$ and 20 and $21 \%$, respectively. Plasma samples were collected $1 \mathrm{~d}$ before slaughter to examine biomarkers of metabolism, liver function, inflammation, and oxidative stress. The reticulo-rumen mass was recorded at slaughter, and samples of epithelium were harvested from all cows. The expression of 29 genes associated with tight junctions, immune function, and nutrient transport (volatile fatty acids, urea, and trace minerals) was examined. Overfeeding energy led to consistently greater dry matter intake over time, and lowered plasma concentrations of haptoglobin, paraoxonase, bilirubin, fatty acids, and myeloperoxidase (secreted by neutrophils). In contrast, OVE resulted in greater hydroxybutyrate and cholesterol concentrations. A
\end{abstract}

\footnotetext{
Received March 13, 2017.

Accepted August 3, 2017.

${ }^{1}$ Corresponding authors: johan.osorio@sdstate.edu and jloor@ illinois.edu
}

greater reticulo-rumen mass in cows fed OVE did not alter genes associated with tight junctions $(C D L N 1$, CDNL4, OCLN, TJP1), immune function (IL1B, IL10, NFKB1, TLR2, TLR 4, TNF), oxidative stress (SOD1, SOD2), or most nutrient transporters. However, feeding OVE upregulated the acute-phase protein SAA3 by 3.5 -fold and downregulated a volatile fatty acid transporter (SLC16A1) and a $\mathrm{Fe}$ and $\mathrm{Cu}$ transporter (SLC11A2). The lack of effect on mRNA expression along with lower plasma concentrations of inflammation biomarkers indicates that long-term intake of a higher-energy diet ad libitum was not detrimental to ruminal epithelium integrity. In that context, a protective function of SAA3 could be envisioned with a role in opsonizing gram-negative bacteria that produce endotoxins. The long-term control of volatile fatty acid absorption and trace minerals from the rumen in cows overfed energy does not seem to be controlled at the gene transcription level. The relevance of these findings to the nutritional management of pregnant dry cows merits further research.

Key words: nutrition, gene expression, ruminal epithelium

\section{INTRODUCTION}

The rumen contains microorganisms which under "normal" conditions ferment carbohydrates and protein from the feed to gas $\left(\mathrm{CO}_{2}\right.$ and $\left.\mathrm{CH}_{4}\right)$, short-chain fatty acids, and ammonia. It is well established that ruminal epithelium expresses transporters for short-chain fatty acids that allow for efficient absorption (Penner et al., 2009, 2011). Recent data, however, have underscored that feeding incremental levels of cereal grains induces the production of toxic, inflammatory, and unnatural compounds in the rumen (Saleem et al., 2012). The degree to which the ruminal epithelium responds under such conditions is unclear. Evidence indicates that ruminal epithelium could play an "immune role" in the context of preventing the translocation of commensal 
bacteria or its metabolites that could induce a systemic immune response (Trevisi et al., 2014).

To date, most studies of molecular mechanisms in ruminal epithelium have focused on the morphological and molecular adaptations induced by differences in total dietary concentrate (Penner et al., 2011; Minuti et al., 2015). However, there is a lack of research evaluating the molecular changes that occur in the rumen epithelium of cows when the level of dietary energy is increased while maintaining a similar level of dietary concentrate. Besides the focus on genes associated with energy metabolism and VFA transport under such dietary conditions, little information exists regarding the expression of transporters for trace minerals (Fe, $\mathrm{Zn}$, $\mathrm{Cu}$, and $\mathrm{Mn}$ ) and immune-related genes. That information is important because increasing dietary energy content through the use of higher-fermentable feedstuffs can induce production of immune-related compounds that potentially could trigger a response by the ruminal epithelium (Trevisi et al., 2014).

The hypothesis in the present study was that increasing dietary energy content and intake through inclusion of rapidly fermentable carbohydrate while maintaining a similar level of concentrate would alter mRNA expression of genes associated with inflammation, permeability, immunity, and transport of trace minerals. Furthermore, changes in metabolism, immune, and inflammatory responses also would be altered in response to long-term energy overfeeding. Thus, transcriptome and systemic biomarker analyses were used to address the hypothesis and objectives.

\section{MATERIALS AND METHODS}

\section{Animals and Treatments}

All procedures were conducted under protocols approved by the University of Illinois Institutional Animal Care and Use Committee (protocol \#12134). Fourteen nonlactating, nonpregnant multiparous (had completed $3.3 \pm 0.8$ lactations; mean $\pm \mathrm{SD}$ ) Holstein cows (initial $\mathrm{BW}=717 \pm 39 \mathrm{~kg}$; initial $\mathrm{BCS}=3.31$ \pm 0.14 ) were enrolled in the experiment and were fed for 3 wk a control diet (lower-energy, CON; $\mathrm{NE}_{\mathrm{L}}=$ $1.30 \mathrm{Mcal} / \mathrm{kg}$ of $\mathrm{DM}$ ) designed to meet $100 \%$ of NRC (2001) requirements. During this time, it was estimated that all cows consumed an average of $110 \pm 5 \%$ of NRC requirements. At the end of the 3 wk, half of the cows were randomly assigned to a higher-energy diet $\left(\mathbf{O V E} ; \mathrm{NE}_{\mathrm{L}}=1.60 \mathrm{Mcal} / \mathrm{kg}\right.$ of $\left.\mathrm{DM}\right)$ and half of the cows continued on CON for 6 wk (Table 1). The diets fed as a TMR were designed to maintain a similar level of forage $(\sim 80 \%)$ and concentrate $(\sim 20 \%)$, while total
Table 1. Ingredient and analyzed nutrient composition of the control (CON) and higher-energy (OVE) diet fed to dry and nonpregnant Holstein cows for a period of $6 \mathrm{wk}$

\begin{tabular}{|c|c|c|}
\hline \multirow[b]{2}{*}{ Item } & \multicolumn{2}{|c|}{ Diet } \\
\hline & $\mathrm{CON}$ & OVE \\
\hline \multicolumn{3}{|l|}{ Ingredient, $\%$ of DM } \\
\hline Alfalfa hay & 2.00 & 5.97 \\
\hline Alfalfa silage & 8.88 & 13.61 \\
\hline Ground shelled corn & 4.04 & 12.56 \\
\hline Corn silage & 33.21 & 54.08 \\
\hline Dicalcium phosphate & 0.79 & 0.70 \\
\hline Limestone & 0.82 & 0.84 \\
\hline Magnesium chloride & 0.46 & 0.70 \\
\hline Magnesium oxide & 0.40 & 0.38 \\
\hline Magnesium sulfate & 0.99 & 1.05 \\
\hline Mineral-vitamin premix ${ }^{1}$ & 0.20 & 0.21 \\
\hline Salt & 0.20 & 0.14 \\
\hline Soybean meal, $48 \%$ CP & 11.56 & 4.35 \\
\hline Urea & 0.20 & 0.19 \\
\hline Vitamin $\mathrm{A}^{2}$ & 0.01 & 0.01 \\
\hline Vitamin $D^{3}$ & 0.01 & 0.01 \\
\hline Vitamin $E^{4}$ & 0.26 & 0.24 \\
\hline Wheat straw & 35.97 & - \\
\hline Whole cottonseeds & - & 4.98 \\
\hline Total forage, $\%$ of DM & 80.06 & 78.64 \\
\hline Total concentrate, $\%$ of DM & 19.94 & 21.38 \\
\hline \multicolumn{3}{|l|}{ Chemical analysis } \\
\hline $\mathrm{NE}_{\mathrm{L}}{ }^{5} \mathrm{Mcal} / \mathrm{kg}$ & 1.30 & 1.60 \\
\hline $\mathrm{CP}, \%$ of DM & 14.08 & 14.45 \\
\hline $\mathrm{ADF}, \%$ of $\mathrm{DM}$ & 34.40 & 26.30 \\
\hline $\mathrm{NDF}, \%$ of DM & 50.40 & 38.30 \\
\hline
\end{tabular}

${ }^{1}$ Contained a minimum of $5 \% \mathrm{Mg}, 10 \% \mathrm{~S}, 7.5 \% \mathrm{~K}, 2.0 \% \mathrm{Fe}, 3.0 \% \mathrm{Zn}$, $3.0 \% \mathrm{Mn}, 5,000 \mathrm{mg} / \mathrm{kg}$ of Cu, $250 \mathrm{mg} / \mathrm{kg}$ of I, $40 \mathrm{mg} / \mathrm{kg}$ of Co, 150 $\mathrm{mg} / \mathrm{kg}$ of Se, $2,200 \mathrm{IU} / \mathrm{kg}$ of vitamin $\mathrm{A}, 660 \mathrm{IU} / \mathrm{kg}$ of vitamin $\mathrm{D}_{3}$, and $7,700 \mathrm{IU} / \mathrm{kg}$ of vitamin $\mathrm{E}$.

${ }^{2}$ Contained 30,000 kIU/kg.

${ }^{3}$ Contained 5,009 kIU/kg.

${ }^{4}$ Contained 44,000 IU/kg.

${ }^{5}$ Calculated using the Dairy Cattle NRC (2001) model. Inputs were 8.5 $\mathrm{kg}$ of DMI for CON or $14.4 \mathrm{~kg}$ of DMI for OVE. A BW of $717 \mathrm{~kg}$ was the input for both diets.

energy content was varied. Cows were offered feed once daily at $0600 \mathrm{~h}$ and had unlimited access to fresh water. Cows in CON were feed restricted to consume only $100 \%$ of NRC requirements, whereas cows in OVE had ad libitum access to feed. It was estimated that OVE cows consumed nutrients at $\sim 180 \%$ of NRC requirements. Cows were housed in ventilated indoor pens (10 $\mathrm{m} \times 15 \mathrm{~m}$; photoperiod of $8 \mathrm{~h}$ light and $16 \mathrm{~h}$ dark) equipped with individual electronic transmission gates and transponders (American Calan, Northwood, NH) for access to feed. Each pen had 10 sand-bedded free stalls with at least 1 stall per cow.

\section{Sample Collection}

Blood samples were collected before the morning feeding from the coccygeal vein or artery the day be- 
fore slaughter. Samples were collected into evacuated tubes (Vacutainer, Becton Dickinson and Co., Franklin Lakes, NJ) containing clot activator or lithium heparin. After blood collection, tubes containing lithium heparin were placed on ice, whereas the tubes with clot activator were kept $\sim 30$ min at $21^{\circ} \mathrm{C}$ until centrifugation. Serum and plasma were obtained by centrifugation of clot activator and lithium heparin tubes, respectively, at $1,900 \times g$ for $15 \mathrm{~min}$ at $4^{\circ} \mathrm{C}$ and frozen at $-80^{\circ} \mathrm{C}$ until later analysis.

Cows were euthanized at the College of Veterinary Medicine diagnostic facilities (University of Illinois) via captive bolt stunning followed by exsanguination. Immediately after death, rumen tissue from the ventral blind sac was quickly excised and washed with sterile $0.01 M$ PBS (pH 6.8). The papillae were scraped to remove attached feed particles and rinsed 3 times to remove the nonadherent bacteria. Epithelium for extracting RNA was separated from the muscle layers and transferred into liquid $\mathrm{N}$ within 5 min of exsanguination and stored at $-80^{\circ} \mathrm{C}$.

\section{Blood Analyses}

Biomarkers were analyzed in lithium heparin samples at $37^{\circ} \mathrm{C}$ following the procedures previously described by Jacometo et al. (2015) in a clinical auto-analyzer (ILAB 600, Instrumentation Laboratory, Lexington, MA).

\section{RNA Isolation and cDNA Synthesis}

Total RNA was extracted from frozen rumen epithelial tissue (100-200 mg) using QIAZol Lysis Reagent with the miRNeasy Mini Kit (catalog no. 217004, Qiagen, Hilden, Germany). Tissue was completely homogenized in $1 \mathrm{~mL}$ of QIAZol Reagent in $2 \mathrm{~mL}$ of RNase/ DNase-free tubes with an O-ring. One bead (catalog no. $69989,5 \mathrm{~mm}$, Qiagen) per tube was added using the Qiagen bead dispenser. The tubes were loaded into a semi-automated homogenizer and the samples homogenized twice for $30 \mathrm{~s}$ with a 1-min incubation time on ice. Subsequently, $200 \mu \mathrm{L}$ of chloroform was added to each sample and placed at room temperature for $3 \mathrm{~min}$ after shaking vigorously for $15 \mathrm{~s}$. The upper phase was transferred into a new collection tube without disturbing the mid and lower phase after centrifugation at $12,000 \times g$ at $4^{\circ} \mathrm{C}$ for $15 \mathrm{~min}$. Subsequently, $750 \mu \mathrm{L}$ of $100 \%$ ethanol was added to each sample and mixed well. Total RNA plus miRNA extraction was performed following the procedure recommended by Qiagen. Eighty microliters of DNase I digestion mix (catalog no. 79254, Qiagen) was added to each column to re- move genomic DNA. Lastly, $50 \mu \mathrm{L}$ of RNase-free water was added to each sample to elute total RNA. The RNA concentration was measured with a NanoDrop ND-1000 spectrophotometer (NanoDrop Technologies). The purity of RNA was assessed by ratio of optical density at $260 / 280 \mathrm{~nm}\left(\mathrm{OD}_{260 / 280}\right)$, which was above 2.0 for all samples. The RNA integrity was evaluated via electrophoretic analysis of $28 \mathrm{~S}$ and $18 \mathrm{~S}$ rRNA subunits using a 2100 Bioanalyzer (Agilent Technologies, Santa Clara, CA). The average RNA integrity number value for samples was $7.2 \pm 0.5$. Total RNA yield averaged $1,179 \pm 759 \mathrm{ng} / \mu \mathrm{L}$ (or $58.9 \pm 38 \mu \mathrm{g}$ of total RNA per sample).

\section{Quantitative PCR, Design, and Evaluation of Primers}

For quantitative PCR (qPCR), cDNA was synthesized using $100 \mathrm{ng}$ of RNA, $1 \mu \mathrm{g}$ of dT18 (Operon Biotechnologies, Huntsville, AL), $1 \mu \mathrm{L}$ of $10 \mathrm{mmol} / \mathrm{L}$ dNTP mix (Invitrogen Corp., Carlsbad, CA), $1 \mu \mathrm{L}$ of random primer $\mathrm{p}(\mathrm{dN}) 6$ (Roche catalog no. 11034731 001, Roche Diagnostics GmbH, Mannheim, Germany), and $10 \mu \mathrm{L}$ of DNase/RNase-free water. The mixture was incubated at $65^{\circ} \mathrm{C}$ for $5 \mathrm{~min}$ and kept on ice for $3 \mathrm{~min}$. A total of $6 \mu \mathrm{L}$ of master mix composed of $4.5 \mu \mathrm{L}$ of $5 \times$ first-strand buffer, $1 \mu \mathrm{L}$ of $0.1 \mathrm{M}$ dithiothreitol, $0.25 \mu \mathrm{L}$ (50 U) of SuperScript III RT (Invitrogen Corp.), and $0.25 \mu \mathrm{L}$ of RNase Inhibitor (10 U; Promega, Madison, WI) was added. The reaction was performed in an Eppendorf Mastercycler Gradient (Eppendorf, Hamburg, Germany) using the following temperature program: $25^{\circ} \mathrm{C}$ for $5 \mathrm{~min}, 50^{\circ} \mathrm{C}$ for $60 \mathrm{~min}$, and $70^{\circ} \mathrm{C}$ for $15 \mathrm{~min}$. The cDNA was then diluted 1:4 (vol:vol) with DNase/ RNase-free water.

Quantitative PCR was performed using $4 \mu \mathrm{L}$ of diluted cDNA (dilution 1:4) combined with $6 \mu \mathrm{L}$ of a mixture composed of $5 \mu \mathrm{L}$ of $1 \mu \mathrm{L}$ SYBR Green master mix (Applied Biosystems, Waltham, MA), $0.4 \mu \mathrm{L}$ each of $10 \mu M$ forward and reverse primers, and 0.2 $\mu \mathrm{L}$ of DNase/RNase-free water in a MicroAmp Optical 384-Well Reaction Plate (Applied Biosystems). Each sample was run in triplicate and a 6-point relative standard curve plus the nontemplate control was used (User Bulletin \#2, Applied Biosystems). The reactions were performed in an ABI Prism 7900 HT SDS instrument (Applied Biosystems) using the following conditions: 2 min at $50^{\circ} \mathrm{C}, 10 \mathrm{~min}$ at $95^{\circ} \mathrm{C}, 40$ cycles of $15 \mathrm{~s}$ at $95^{\circ} \mathrm{C}$ (denaturation), and $1 \mathrm{~min}$ at $60^{\circ} \mathrm{C}$ (annealing and extension). The presence of a single PCR product was verified by the dissociation protocol using incremental temperatures to $95^{\circ} \mathrm{C}$ for $15 \mathrm{~s}$ plus $65^{\circ} \mathrm{C}$ for $15 \mathrm{~s}$. Data were calculated with the 7900 HT Sequence Detection Systems Software (version 2.2.1, Applied Biosystems). 
The final data were normalized using the geometric mean of CKLF-like MARVEL transmembrane domain containing 6 (CMTM6), dystrobrevin binding protein 1 (DBNDD2), and DEAD (Asp-Glu-Ala-Asp) box polypeptide 54 (DDX54). These genes were previously validated in our laboratory for use with ruminal epithelium (Naeem et al., 2012).

Primer sequences for genes evaluated in this study are reported in Supplemental Table S1 (https://doi.org/ 10.3168/jds.2017-12866). Primers were designed using Primer Express 3.0 with minimum amplicon size of 80 bp (when possible amplicons of 100-150 bp were chosen) and limited 3' G+C (Applied Biosystems). When possible, primers were designed to fall across exon-exon junctions. Primers were aligned against publicly available databases using BLASTN (https://blast.ncbi.nlm .nih.gov/Blast.cgi) at National Center for Biotechnology Information and the University of California Santa Cruz Cow (Bos taurus) Genome Browser gateway (https://genome.ucsc.edu/index.html). Prior to qPCR, primers were tested in a $20-\mu \mathrm{L}$ PCR reaction using the same protocol described for qPCR except for the final dissociation protocol. For primer testing we used a universal reference cDNA (RNA mixture from 5 different bovine tissues) to ensure identification of desired genes. Five microliters of the PCR product was run in a $2 \%$ agarose gel stained with ethidium bromide $(2 \mu \mathrm{L})$. The remaining $15 \mu \mathrm{L}$ was cleaned using QIAquick PCR Purification Kit (Qiagen) and sequenced at the Core DNA Sequencing Facility of the Roy J. Carver Biotechnology Center at the University of Illinois, Urbana-Champaign. Only those primers that did not present primer-dimer, a single band at the expected size in the gel, and had the right amplification product (verified by sequencing; Supplemental Table S2; https://doi.org/10.3168/ jds.2017-12866) were used for qPCR. The accuracy of a primer pair also was evaluated by the presence of a unique peak during the dissociation step at the end of qPCR. Efficiency of PCR amplification for each gene was calculated using the standard curve method $[\mathrm{E}=$ $10^{(-1 / \text { slope })}$ ] (Supplemental Table S3; https://doi.org/10 $.3168 /$ jds.2017-12866). Efficiency cutoff during qPCR was between 1.80 and 2.1 .

\section{Statistical Analysis}

All data were analyzed with the PROC MIXED procedure of SAS (SAS Institute Inc., Cary, NC) with each animal as the experimental unit. After normalization with the geometric mean of the 3 internal control genes, the triplicate $\mathrm{qPCR}$ data for each gene were averaged and then $\log _{2}$ transformed before statistical analysis. For mRNA expression, reticulo-rumen mass, and blood biomarkers, the fixed effect in the model was diet, and cow within diet was designated as the random effect. For DMI data, the fixed effects in the model were diet, day on experiment, and diet $\times$ day. In this case a repeated statement was used, with first-order autoregressive $[\mathrm{AR}(1)]$ as the covariate structure used because it resulted in the lowest Bayesian information criterion. In both models the Kenward-Roger statement was used for computing the denominator degrees of freedom.

\section{RESULTS AND DISCUSSION}

Blood concentrations of biomarkers are reported in Table 2. The greater $(P<0.05)$ concentrations of cholesterol (3.90 vs. $2.64 \mathrm{mmol} / \mathrm{L})$ and BHB (0.43 vs. 0.22 $\mathrm{mmol} / \mathrm{L})$ as well as lower $(P<0.05)$ fatty acids $(0.07$ vs. $0.17 \mathrm{mmol} / \mathrm{L}$ ) in cows fed OVE agree with previous research reporting a positive energy balance in cows fed dietary energy in excess of requirements (Danicke et al., 2014). Regarding liver function, a greater $(P<$ 0.05) concentration of aspartate transaminase (AST; 78.8 vs. $64.3 \mathrm{U} / \mathrm{L})$ was observed, whereas bilirubin was lower $(P<0.05)$ in cows fed OVE $(0.89$ vs. $1.49 \mu \mathrm{g} /$ mol). The higher level of AST and the greater cholesterol concentration (3.90 vs. $2.64 \mathrm{mmol} / \mathrm{L})$ could be attributed to the greater liver mass (1.42 vs. 1.10 as $\%$ of BW; data not shown) in the OVE cows, and the associated increase in liver workload (Abeni et al., 2012) including lipoprotein metabolism and breakdown of heme (both important functions of the liver).

Inflammatory biomarkers in OVE cows were within the normal range, with lower concentrations of paraoxonase ( $P=0.05 ; 92.1$ vs. $113 \mathrm{U} / \mathrm{mL}$; Bionaz et al., 2007) and haptoglobin $(P=0.08 ; 0.14$ vs. $0.27 \mathrm{~g} / \mathrm{L}$; Bertoni and Trevisi, 2013). Although AST was greater than reference values for cows with optimal liver function (Bertoni and Trevisi, 2013), these data indicate that despite the greater workload of the liver induced by the marked overfeeding, cows did not experience a state of inflammation or oxidative stress. Furthermore, the lack of systemic inflammatory response based on biomarker analyses suggest that the greater energy intake did not induce detrimental effects on the ruminal epithelium. An increase in ruminal epithelium permeability could cause a systemic inflammatory response (Minuti et al., 2014).

Out of the 29 target genes evaluated (Table 3), only IL6 was not expressed (i.e., cycle threshold value > 30 ), which agrees with our previous work with ruminal epithelium in peripartal Holstein cows (Minuti et al., 2015). The absence of differences in the expression of genes encoding for cell adhesion and tight-junction (TJ) proteins in cows fed OVE (CDLN1, CDLN4, 
Table 2. Concentrations of biomarkers of metabolism, liver function, inflammation, and oxidative stress in plasma from dry and nonpregnant Holstein cows fed a control (CON; $1.30 \mathrm{Mcal} / \mathrm{kg}$ of DM) or higher-energy (OVE; $1.60 \mathrm{Mcal} / \mathrm{kg}$ of DM) diet for a period of $6 \mathrm{wk}$

\begin{tabular}{|c|c|c|c|c|}
\hline \multirow[b]{2}{*}{ Item } & \multicolumn{2}{|c|}{ Diet } & \multirow[b]{2}{*}{ SEM } & \multirow[b]{2}{*}{$P$-value } \\
\hline & $\mathrm{CON}$ & OVE & & \\
\hline \multicolumn{5}{|l|}{ Metabolism } \\
\hline Glucose, mmol/L & 4.52 & 4.69 & 0.09 & 0.20 \\
\hline Cholesterol, mmol/L & 2.64 & 3.90 & 0.24 & 0.004 \\
\hline Fatty acids, $\mathrm{mmol} / \mathrm{L}$ & 0.17 & 0.07 & 0.02 & 0.002 \\
\hline $\mathrm{BHB}, \mathrm{mmol} / \mathrm{L}$ & 0.22 & 0.43 & 0.03 & 0.0002 \\
\hline Urea, mmol/L & 4.49 & 4.36 & 0.36 & 0.81 \\
\hline \multicolumn{5}{|l|}{ Liver function } \\
\hline Aspartate aminotransferase, $\mathrm{U} / \mathrm{L}$ & 64.3 & 78.8 & 4.37 & 0.04 \\
\hline$\gamma$-Glutamyl transpeptidase, U/L & 23.9 & 23.0 & 1.47 & 0.67 \\
\hline Bilirubin, $\mu \mathrm{mol} / \mathrm{L}$ & 1.49 & 0.89 & 0.13 & 0.005 \\
\hline Total protein, g/L & 76.9 & 75.1 & 1.47 & 0.40 \\
\hline \multicolumn{5}{|l|}{ Inflammation } \\
\hline Ceruloplasmin, $\mu \mathrm{mol} / \mathrm{L}$ & 3.30 & 3.16 & 0.28 & 0.73 \\
\hline Haptoglobin, g/L & 0.27 & 0.14 & 0.07 & 0.08 \\
\hline Albumin, $g / \mathrm{L}$ & 34.3 & 35.4 & 0.82 & 0.36 \\
\hline Globulin, g/L & 42.6 & 39.7 & 1.77 & 0.27 \\
\hline Paraoxonase, $\mathrm{U} / \mathrm{mL}$ & 113 & 92.1 & 7.43 & 0.05 \\
\hline Myeloperoxidase, U/L & 460 & 411 & 22 & 0.14 \\
\hline \multicolumn{5}{|l|}{ Oxidative stress } \\
\hline $\begin{array}{l}\text { Reactive oxygen metabolites, } \mathrm{mg} \text { of } \mathrm{H}_{2} \mathrm{O}_{2} / 100 \\
\mathrm{~mL}\end{array}$ & 14.0 & 14.0 & 0.71 & 0.98 \\
\hline
\end{tabular}

OCLN, TJP1) indicates that the much greater level of dietary energy intake (Figure 1) did not impair the integrity of the ruminal epithelium. Tight junctions located in the middle layers of ruminal epithelium play a key role in maintaining permeability and preventing the translocation of LPS and other toxins (Penner et al., 2011). Feeding a $65 \%$ high-grain diet to goats decreased mRNA expression of CDLN4, OCLN, and TJP1 and increased $C D L N 1$ in addition to causing profound morphological alterations of the ruminal epithelium, and a deterioration of ruminal function as a consequence of a sharp decrease in $\mathrm{pH}$ and a marked increase in ruminal LPS concentration (Liu et al., 2013). Although it was not feasible to measure ruminal parameters of digestion in the present study, the sustained increase in DMI throughout the whole experimental period for OVE cows (Figure 1) further supports the idea that there was no impairment of ruminal function.

Among the few genes that were affected by feeding OVE, a $\sim 3.6$-fold increase $(P=0.07)$ was observed in the mRNA expression for the acute-phase protein serum amyloid A3 (SAA3; Table 2). Although the precise biological function of SAA in ruminants is not clear, it could play a role in metabolism, inflammatory processes, and opsonization (Ceciliani et al., 2012). For instance, Reigstad et al. (2009) detected greater mRNA expression of $S A A 3$ in mouse colonic epithelial cells as a result of microbial colonization or cultivation of the cells with LPS, suggesting it could play a bactericidal role.
Although the reticulo-rumen mass was greater $(P<$ $0.05 ; 15.5$ vs. $13.3 \mathrm{~kg}$ ) in OVE cows (Figure 1), expression of urea and VFA transporters $(S L C 14 A 1$ and $S L C 16 A 3)$ did not differ $(P>0.10)$ and feeding OVE led to lower $(P<0.05)$ mRNA expression of SLC16A1, a transporter catalyzing movement of lactate and pyruvate across plasma membranes. The lack of change in urea transporter expression agrees with the similar concentration of plasma urea (Table 2). However, the lower expression of $S L C 16 A 1$ seems unexpected given that OVE cows consumed an average of $8 \mathrm{~kg}$ more DM per day (Figure 1) and although not measured in the present study likely had greater rates of fermentation and production of VFA (Bauman et al., 1971; Sutton et al., 2003). The 2-fold greater BHB concentration in plasma of OVE cows supports the idea of greater VFA production (i.e., greater butyrate production likely accounted for the BHB response). It could be possible that abundance of SLC16A1 protein was affected by OVE but it was not measured in the present study.

Most previous studies addressing the expression of genes associated with VFA absorption in the ruminal epithelium have focused on the effect of higher diet fermentability (via the inclusion of concentrates) resulting in a greater production of VFA, changes in their proportions, and a possible decrease in ruminal $\mathrm{pH}$. In the short term, the ruminal epithelium responds mainly through cellular functional adaptations associated with an increase in gene expression and activity of proteins involved in the transport of VFA (Schurmann et al., 
Table 3. mRNA expression ( $\log _{2}$ back-transformed LSM) among genes in ruminal epithelium of dry and nonpregnant Holstein cows fed a control (CON; $1.30 \mathrm{Mcal} / \mathrm{kg}$ of DM) or higher-energy (OVE; $1.60 \mathrm{Mcal} / \mathrm{kg}$ of DM) diet for a period of $6 \mathrm{wk}$

\begin{tabular}{|c|c|c|c|c|}
\hline \multirow[b]{2}{*}{ Gene } & \multicolumn{2}{|c|}{ Diet } & \multirow[b]{2}{*}{ SEM } & \multirow[b]{2}{*}{$P$-value } \\
\hline & $\mathrm{CON}$ & OVE & & \\
\hline \multicolumn{5}{|c|}{ Tight junctions } \\
\hline$C D L N 1$ & 1.11 & 0.91 & 0.13 & 0.15 \\
\hline$C D L N_{4}$ & 1.16 & 1.07 & 0.14 & 0.57 \\
\hline$O C L N$ & 0.98 & 0.89 & 0.11 & 0.38 \\
\hline TJP1 & 1.04 & 1.00 & 0.05 & 0.52 \\
\hline \multicolumn{5}{|c|}{ Immune function and inflammation } \\
\hline$C D 45$ & 0.88 & 1.09 & 0.15 & 0.17 \\
\hline$I L 1 B$ & 0.14 & 0.27 & 0.76 & 0.38 \\
\hline IL10 & 0.52 & 0.80 & 0.42 & 0.31 \\
\hline$I R A K 1$ & 0.97 & 0.88 & 0.09 & 0.28 \\
\hline NFKB1 & 1.07 & 0.95 & 0.10 & 0.27 \\
\hline NFKBIA & 0.95 & 0.91 & 0.07 & 0.47 \\
\hline SААЗ & 0.21 & 0.75 & 0.66 & 0.07 \\
\hline STAT3 & 0.87 & 0.94 & 0.07 & 0.24 \\
\hline TLR2 & 0.94 & 1.00 & 0.19 & 0.19 \\
\hline TLR4 & 0.95 & 1.08 & 0.10 & 0.21 \\
\hline$T N F$ & 0.93 & 1.03 & 0.15 & 0.47 \\
\hline TOLLIP & 0.81 & 0.79 & 0.08 & 0.75 \\
\hline \multicolumn{5}{|c|}{ Oxidative stress } \\
\hline SOD1 & 0.99 & 0.94 & 0.10 & 0.62 \\
\hline SOD2 & 0.82 & 0.87 & 0.08 & 0.52 \\
\hline \multicolumn{5}{|c|}{ Monocarboxylate and urea transport } \\
\hline$S L C 14 A 1$ & 0.78 & 0.69 & 0.13 & 0.35 \\
\hline SLC16A1 & 0.83 & 0.69 & 0.08 & 0.04 \\
\hline SLC16A3 & 0.90 & 0.92 & 0.08 & 0.82 \\
\hline \multicolumn{5}{|c|}{ Trace mineral transport } \\
\hline SLC11A2 & 0.96 & 0.81 & 0.09 & 0.06 \\
\hline SLC30A1 & 0.90 & 0.79 & 0.20 & 0.50 \\
\hline SLC30A10 & 0.96 & 0.85 & 0.35 & 0.74 \\
\hline SLC31A1 & 0.98 & 0.88 & 0.15 & 0.49 \\
\hline SLC39A1 & 1.04 & 1.00 & 0.08 & 0.58 \\
\hline SLC39A3 & 1.08 & 0.97 & 0.13 & 0.41 \\
\hline \multicolumn{5}{|c|}{ Hydroxycarboxylic acid receptor } \\
\hline HCAR2 & 0.86 & 0.92 & 0.32 & 0.85 \\
\hline
\end{tabular}

2014). In the long term, however, the response appears mostly related to morphological adaptations [e.g., hyperplasia and hypertrophy of the ruminal epithelium to increase the absorptive surface (Penner et al., 2011)].

Previous research studying the response in SLC16A1 to higher dietary energy in dairy cows detected either no change (Steele et al., 2012; Schurmann et al., 2014) or an increase in expression (Kuzinski and Rontgen, 2011; Yan et al., 2014). Expression of this transporter seems to be sensitive to dietary concentrate level because Metzler-Zebeli et al. (2013) detected an increase in SLC16A1 in growing goats only when dietary concentrate reached $60 \%$ of total diet, with expression being unaffected at $0 \%$ and $30 \%$ of dietary concentrate. In general, the studies reporting greater expression of SLC16A1 fed a high proportion of concentrate resulting in a noticeable decrease in ruminal $\mathrm{pH}$ and were of short experimental duration (Kuzinski and Rontgen, 2011; Yan et al., 2014; Zebeli et al., 2015). The present study is the first to detect a lower expression of
SLC16A1 in cows chronically overfed energy; thus, we speculate that this response represents an adaptive mechanism to the long-term feeding as suggested by Penner et al. (2011). The fact that cows overfed energy had a greater reticulo-rumen mass (Figure 1) could be taken as an indication of greater absorptive surface to efficiently handle production of VFA. Thus, this type of long-term adaptation would make it unnecessary for the epithelium to upregulate the SLC16A1 transport system.

Regarding trace mineral transporters, to our knowledge, no studies have been published on their expression in the ruminal epithelium. Those that were the focus of the present study are involved in the inflammatory response (Gruys et al., 2005). No differences $(P>0.10)$ in the expression of the SLC30 and SLC39 Zn family of transporters or the SLC31A1 Cu transporter were observed. However, there was a lower expression $(P=$ 0.06) in OVE cows of the divalent metal transporter $S L C 11 A 2$. This gene is widely expressed in various tis- 
sues, especially in duodenal enterocytes, and plays a crucial role in the absorption of $\mathrm{Fe}$ and other divalent transition metals (Garrick et al., 2003). Iron is an essential element for many vital functions such as oxidative metabolism, erythropoietic function, and immune cell response. However, in excess Fe is toxic; hence, its circulating levels need to be maintained at a very narrow range. As there is no active excretion mechanism of Fe, its homeostasis depends on the recycling in erythrocyte hemoglobin and intestinal absorption.

The present study underscores the potential contribution of ruminal epithelium (along with intestinal absorption) in the maintenance of Fe homeostasis. The lower expression of this gene due to feeding OVE is
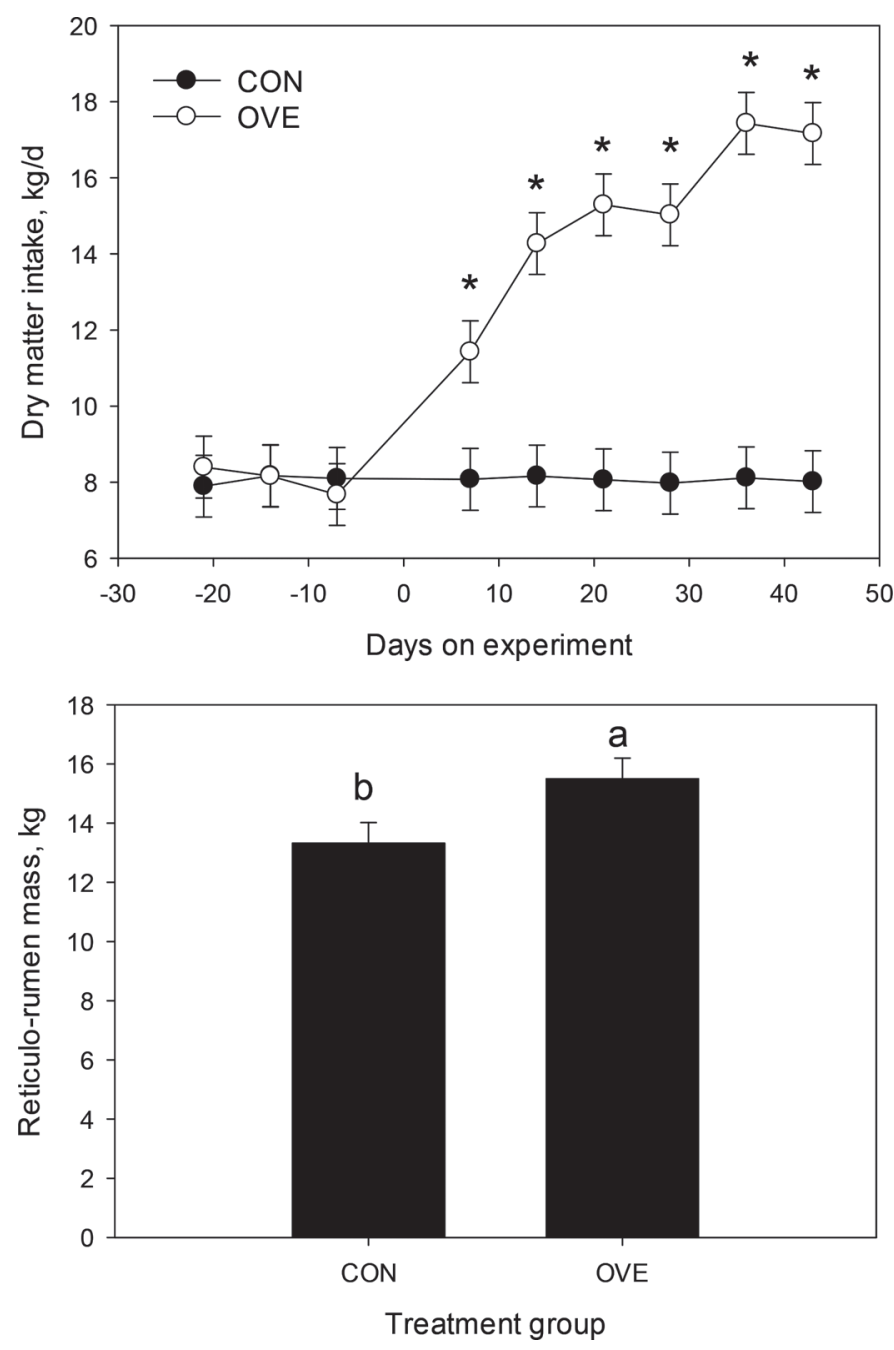

Figure 1. Weekly DMI (top panel) and reticulo-rumen mass (bottom panel) at slaughter in dry and nonpregnant Holstein cows fed a control $(\mathrm{CON} ; 1.30 \mathrm{Mcal} / \mathrm{kg}$ of $\mathrm{DM})$ or higher-energy (OVE; 1.60 $\mathrm{Mcal} / \mathrm{kg}$ of $\mathrm{DM})$ diet for a period of $6 \mathrm{wk}$. ${ }^{*}$ Diet $\times$ time, $P<0.05$; ${ }^{\mathrm{a}, \mathrm{b}}$ Means differ, $P<0.05$. Values are means, with $\mathrm{SE}$ represented by vertical bars. consistent with the work of Hansen et al. (2010) who detected a trend for lower expression of the divalent transporter 1 but a lack of change in mRNA in duodenal tissue of calves fed higher levels of Fe. Therefore, the present data indicate a possible excess of Fe intake as a result of the overfeeding, which elicited a decrease in its absorption to maintain adequate levels. The welldocumented interaction between Fe absorption with other metals, mainly $\mathrm{Cu}, \mathrm{Zn}$, and $\mathrm{Mn}$, should also be kept in mind (Arredondo et al., 2003; Hansen et al., 2010). Therefore, the interaction between $\mathrm{Fe}$ and $\mathrm{Cu}$ could be one of the causes for the observed difference in expression of SLC11A2. Both SLC11A2 and SLC31A1 are $\mathrm{Cu}$-specific transporters that play important roles in absorption as shown by the work of Arredondo et al. (2003) in which culturing Caco-2 cells with increasing concentrations of $\mathrm{Cu}$ decreased $\mathrm{Fe}$ uptake. Therefore, $\mathrm{Fe}$ can interfere with the absorption of $\mathrm{Cu}$ in 2 ways (i.e., by decreasing $S L C 11 A 2$ gene expression and competing for the transport protein).

Most studies that have examined the effect of supplementation with $\mathrm{Fe}$ on $\mathrm{Cu}$ status have been performed with high concentrations of $\mathrm{Fe}$, but Bremner et al. (1987) observed a decrease in the amount of hepatic $\mathrm{Cu}$ concentration in calves only when supplemented with $250 \mathrm{mg}$ of $\mathrm{Fe} / \mathrm{kg}$ of $\mathrm{DM}$ in the diet. In the present study, the calculated concentrations of $\mathrm{Fe}$ in the $\mathrm{CON}$ and OVE diets, taking only into account the mineral premix and dicalcium phosphate [ 10,000 $\mathrm{mg}$ of $\mathrm{Fe} / \mathrm{kg}$ (Kerr et al., 2008)] was $\sim 120 \mathrm{mg} \mathrm{Fe} / \mathrm{kg}$ of DM, which does not seem excessively high. However, the average calculated daily intakes were 952 and $1,851 \mathrm{mg} / \mathrm{d}$ for $\mathrm{CON}$ and OVE, which far exceed current recommendations (NRC, 2001), especially in the OVE treatment. In addition, the contributions of Fe-rich feeds like alfalfa were not taken into account. Another indirect sign that could be indicative of an interference in $\mathrm{Cu}$ absorption in OVE cows is the $22 \%$ lower $(P<0.05)$ concentration of plasma paraoxonase.

We speculate a biological link between $\mathrm{Cu}$ and paraoxonase in OVE cows based on data from rats, where animals fed a diet deficient in $\mathrm{Cu}$ (not in $\mathrm{Zn}$ ) had very low liver $\mathrm{Cu}$ concentration and a $22 \%$ decrease in paraoxonase concentration (Klevay, 2004). It is noteworthy that ceruloplasmin concentrations in plasma, an indicator of $\mathrm{Cu}$ status (Blakley and Hamilton, 1985), were within a normal range and unaffected $(P=0.73)$ in OVE cows. Thus, although this response supports the view of an absence of inflammation (Gruys et al., 2005), it does not seem to support the idea that $\mathrm{Cu}$ status was affected by feeding OVE.

In conclusion, the lack of effect on the mRNA expression of key genes related to TJ, inflammation, and oxi- 
dative stress along with a lower plasma concentration of inflammation biomarkers indicates that long-term consumption of higher-energy diets ad libitum was not detrimental to the integrity of ruminal epithelium. The marked increase in DMI over time and the greater plasma concentrations of BHB when cows were overfed energy indicate normal rumen function, absorption, and metabolism of VFA. The long-term control of VFA and trace mineral absorption from the rumen in cows chronically overfed energy does not seem to be controlled at the gene transcription level. The relevance of these findings to the nutritional management of pregnant dry cows merits further research.

\section{ACKNOWLEDGMENTS}

Afshin Hosseini (HO 4596/1-1) received fellowship support from the German Research Foundation (DFG). Partial support for the conduct of the project was provided by the University of Illinois Campus Research Board, and Hatch funds under project ILLU-538-914, National Institute of Food and Agriculture, Washington, DC. The helpful discussions with J. K. Drackley (Department of Animal Sciences, University of Illinois, Urbana) during the design of the study are greatly appreciated.

\section{REFERENCES}

Abeni, F., L. Calamari, L. Stefanini, and G. Pirlo. 2012. Effect of average daily gain on body size, metabolism, and milk production of Italian Holstein heifers raised on two different planes of nutrition and calving at two different ages. Livest. Sci. 149:7-17. https://doi .org/10.1016/j.livsci.2012.06.003.

Arredondo, M., P. Munoz, C. V. Mura, and M. T. Nunez. 2003. Dmt1, a physiologically relevant apical $\mathrm{cu}^{1+}$ transporter of intestinal cells. Am. J. Physiol. Cell Physiol. 284:C1525-C1530. https://doi.org/ 10.1152/ajpcell.00480.2002.

Bauman, D. E., C. L. Davis, and H. F. Bucholtz. 1971. Propionate production in the rumen of cows fed either a control or highgrain, low-fiber diet. J. Dairy Sci. 54:1282-1287. https://doi.org/ 10.3168/jds.S0022-0302(71)86021-6.

Bertoni, G., and E. Trevisi. 2013. Use of the liver activity index and other metabolic variables in the assessment of metabolic health in dairy herds. Vet. Clin. North Am. Food Anim. Pract. 29:413-431. https://doi.org/10.1016/j.cvfa.2013.04.004.

Bionaz, M., E. Trevisi, L. Calamari, F. Librandi, A. Ferrari, and G. Bertoni. 2007. Plasma paraoxonase, health, inflammatory conditions, and liver function in transition dairy cows. J. Dairy Sci. 90:1740-1750. https://doi.org/10.3168/jds.2006-445.

Blakley, B. R., and D. L. Hamilton. 1985. Ceruloplasmin as an indicator of copper status in cattle and sheep. Can. J. Comp. Med. 49:405-408.

Bremner, I., W. R. Humphries, M. Phillippo, M. J. Walker, and P. C. Morrice. 1987. Iron induced copper deficiency in calves: Doseresponse relationships and interactions with molybdenum and sulphur. Anim. Prod. 45:403-414.

Ceciliani, F., J. J. Ceron, P. D. Eckersall, and H. Sauerwein. 2012. Acute phase proteins in ruminants. J. Proteomics 75:4207-4231. https://doi.org/10.1016/j.jprot.2012.04.004.
Danicke, S., U. Meyer, J. Winkler, K. Schulz, S. Ulrich, J. Frahm, S. Kersten, J. Rehage, G. Breves, S. Haussler, H. Sauerwein, and L. Locher. 2014. Description of a bovine model for studying digestive and metabolic effects of a positive energy balance not biased by lactation or gravidity. Arch. Anim. Nutr. 68:460-477. https://doi .org/10.1080/1745039X.2014.973243.

Garrick, M. D., K. G. Dolan, C. Horbinski, A. J. Ghio, D. Higgins, M. Porubcin, E. G. Moore, L. N. Hainsworth, J. N. Umbreit, M. E. Conrad, L. Feng, A. Lis, J. A. Roth, S. Singleton, and L. M. Garrick. 2003. Dmt1: A mammalian transporter for multiple metals. Biometals 16:41-54.

Gruys, E., M. J. Toussaint, T. A. Niewold, and S. J. Koopmans. 2005. Acute phase reaction and acute phase proteins. J. Zhejiang Univ. Sci. B 6:1045-1056. https://doi.org/10.1631/jzus.2005.B1045.

Hansen, S. L., M. S. Ashwell, A. J. Moeser, R. S. Fry, M. D. Knutson, and J. W. Spears. 2010. High dietary iron reduces transporters involved in iron and manganese metabolism and increases intestinal permeability in calves. J. Dairy Sci. 93:656-665. https://doi.org/ $10.3168 /$ jds.2009-2341.

Jacometo, C. B., J. S. Osorio, M. Socha, M. N. Correa, F. PiccioliCappelli, E. Trevisi, and J. J. Loor. 2015. Maternal consumption of organic trace minerals alters calf systemic and neutrophil mRNA and microRNA indicators of inflammation and oxidative stress. J. Dairy Sci. 98:7717-7729. https://doi.org/10.3168/jds.2015-9359.

Kerr, B. J., C. J. Ziemer, T. E. Weber, S. L. Trabue, B. L. Bearson, G. C. Shurson, and M. H. Whitney. 2008. Comparative sulfur analysis using thermal combustion or inductively coupled plasma methodology and mineral composition of common livestock feedstuffs. J. Anim. Sci. 86:2377-2384. https://doi.org/10.2527/jas.2007-0811.

Klevay, L. M. 2004. Ischemic heart disease as deficiency disease. Cell. Mol. Biol. 50:877-884.

Kuzinski, J., and M. Rontgen. 2011. The mRNA and protein expression of ruminal MCT1 is increased by feeding a mixed hay/concentrate diet compared with hay ad libitum diet (short communication). Archiv Fur Tierzucht-Arch. Anim. Breeding 54:280-286.

Liu, J. H., T. T. Xu, Y. J. Liu, W. Y. Zhu, and S. Y. Mao. 2013. A high-grain diet causes massive disruption of ruminal epithelial tight junctions in goats. Am. J. Physiol. Regul. Integr. Comp. Physiol. 305:R232-R241. https://doi.org/10.1152/ajpregu.00068 .2013.

Metzler-Zebeli, B. U., M. Hollmann, S. Sabitzer, L. Podstatzky-Lichtenstein, D. Klein, and Q. Zebeli. 2013. Epithelial response to highgrain diets involves alteration in nutrient transporters and $\mathrm{Na}+$ / $\mathrm{K}+$-ATPase mRNA expression in rumen and colon of goats. J. Anim. Sci. 91:4256-4266. https://doi.org/10.2527/jas.2012-5570.

Minuti, A., S. Ahmed, E. Trevisi, F. Piccioli-Cappelli, G. Bertoni, N. Jahan, and P. Bani. 2014. Experimental acute rumen acidosis in sheep: Consequences on clinical, rumen, and gastrointestinal permeability conditions and blood chemistry. J. Anim. Sci. 92:39663977. https://doi.org/10.2527/jas.2014-7594.

Minuti, A., A. Palladino, M. J. Khan, S. Alqarni, A. Agrawal, F. Piccioli-Capelli, F. Hidalgo, F. C. Cardoso, E. Trevisi, and J. J. Loor. 2015. Abundance of ruminal bacteria, epithelial gene expression, and systemic biomarkers of metabolism and inflammation are altered during the peripartal period in dairy cows. J. Dairy Sci. 98:8940-8951. https://doi.org/10.3168/jds.2015-9722.

Naeem, A., J. K. Drackley, J. Stamey, and J. J. Loor. 2012. Role of metabolic and cellular proliferation genes in ruminal development in response to enhanced plane of nutrition in neonatal Holstein calves. J. Dairy Sci. 95:1807-1820. https://doi.org/10.3168/jds .2011-4709.

NRC. 2001. Nutrient Requirements of Dairy Cattle. 7th rev. ed. The National Academies Press, Washington, DC.

Penner, G. B., M. A. Steele, J. R. Aschenbach, and B. W. McBride. 2011. Ruminant nutrition symposium: Molecular adaptation of ruminal epithelia to highly fermentable diets. J. Anim. Sci. 89:11081119. https://doi.org/10.2527/jas.2010-3378.

Penner, G. B., M. Taniguchi, L. L. Guan, K. A. Beauchemin, and M. Oba. 2009. Effect of dietary forage to concentrate ratio on volatile fatty acid absorption and the expression of genes related to volatile 
fatty acid absorption and metabolism in ruminal tissue. J. Dairy Sci. 92:2767-2781. https://doi.org/10.3168/jds.2008-1716.

Reigstad, C. S., G. O. Lunden, J. Felin, and F. Backhed. 2009. Regulation of serum amyloid a3 (saa3) in mouse colonic epithelium and adipose tissue by the intestinal microbiota. PLoS One 4:e5842. https://doi.org/10.1371/journal.pone.0005842.

Saleem, F., B. N. Ametaj, S. Bouatra, R. Mandal, Q. Zebeli, S. M. Dunn, and D. S. Wishart. 2012. A metabolomics approach to uncover the effects of grain diets on rumen health in dairy cows. J. Dairy Sci. 95:6606-6623.

Schurmann, B. L., M. E. Walpole, P. Gorka, J. C. Ching, M. E. Loewen, and G. B. Penner. 2014. Short-term adaptation of the ruminal epithelium involves abrupt changes in sodium and short-chain fatty acid transport. Am. J. Physiol. Regul. Integr. Comp. Physiol. 307:R802-R816. https://doi.org/10.1152/ajpregu.00035.2014.

Steele, M. A., L. Dionissopoulos, O. AlZahal, J. Doelman, and B. W. McBride. 2012. Rumen epithelial adaptation to ruminal acidosis in lactating cattle involves the coordinated expression of insulin-like growth factor-binding proteins and a cholesterolgenic enzyme. J. Dairy Sci. 95:318-327. https://doi.org/10.3168/jds.2011-4465.
Sutton, J. D., M. S. Dhanoa, S. V. Morant, J. France, D. J. Napper, and E. Schuller. 2003. Rates of production of acetate, propionate, and butyrate in the rumen of lactating dairy cows given normal and low-roughage diets. J. Dairy Sci. 86:3620-3633. https://doi .org/10.3168/jds.S0022-0302(03)73968-X.

Trevisi, E., M. Amadori, F. Riva, G. Bertoni, and P. Bani. 2014. Evaluation of innate immune responses in bovine forestomachs. Res. Vet. Sci. 96:69-78. https://doi.org/10.1016/j.rvsc.2013.11.011.

Yan, L., B. Zhang, and Z. Shen. 2014. Dietary modulation of the expression of genes involved in short-chain fatty acid absorption in the rumen epithelium is related to short-chain fatty acid concentration and $\mathrm{pH}$ in the rumen of goats. J. Dairy Sci. 97:5668-5675. https://doi.org/10.3168/jds.2013-7807.

Zebeli, Q., K. Ghareeb, E. Humer, B. U. Metzler-Zebeli, and U. Besenfelder. 2015. Nutrition, rumen health and inflammation in the transition period and their role on overall health and fertility in dairy cows. Res. Vet. Sci. 103:126-136. https://doi.org/10.1016/j .rvsc.2015.09.020 